\title{
LIBERDADE: UMA PONTE ENTRE THOMAS HOBBES E SIMONE DE BEAUVOIR
}

\author{
FREEDOM: A BRIDGE BETWEEN THOMAS HOBBES AND SIMONE DE \\ BEAVOIR
}

\section{Bruna Thomé}

Universidade Federal da Fronteira Sul, Santa Catarina, Brasil. E-mail: bruna_th@hotmail.com

DOI: https://doi.org/10.46550/amormundi.v1i1.10

Recebido em: 02.09.2020

Aceito em: 13.10.2020

\begin{abstract}
Resumo: Tratar do tema da liberdade sempre foi algo complexo na filosofia, pois ainda não sabemos se somos efetivamente livres, até que ponto somos livres, se há uma liberdade, se somos seres livres ou determinados. Para muitos autores como Jean - Paul Sartre estamos condenados a ser livres, a liberdade não é uma dádiva divina dada aos homens (livre arbítrio), mas uma condenação, pois a cada escolha feita (livremente), somos obrigadas a nos responsabilizar pelas consequências dessa escolha. Nessa mesma perspectiva temos Simone de Beauvoir que apresenta uma ideia de liberdade subjetiva, que por sua vez é fundamentada na ideia de intencionalidade, que é sustentada pelos movimentos ontológicos em direção a confirmação desta liberdade. Dessa forma, a liberdade é a premissa primeira da existência, sendo que esta condiçấo de homem livre que permite a fundação de uma moral. Em uma perspectiva não muito distante temos Thomas Hobbes que nega o livre arbítrio, é determinista, mecanicista e materialista. Materialista porque tudo o que se apresenta aos sentidos do homem, incluindo ele mesmo, náo passa de matéria ponderável e apreensível a mente humana e mecanicista em função da própria concepção de movimento da matéria que é delimitada por movimentos exatos assim como o produto matemático. Portanto, a liberdade é negativa. Dessa forma o presente artigo buscará apresentar o ponto de vista destes dois autores, Simone de Beauvoir e Thomas Hobbes e estabelecer entre eles um paralelo, uma ponte possível para compreender o conceito de liberdade.
\end{abstract}

Palavras-chave: Liberdade. Existência. Moralidade. Necessidade.

\begin{abstract}
Dealing with the theme of freedom has always been a complex thing in philosophy, as we still do not know whether we are effectively free, to what extent we are free, whether there is freedom, whether we are free or determined beings. For many authors like Jean - Paul Sartre we are condemned to be free, freedom is not a divine gift given to men (free will), but a condemnation, because with each choice made (freely), we are obliged to take responsibility for the consequences of this choice. In this same perspective, we have Simone de Beauvoir who presents an idea of subjective freedom, which in turn is based on the idea of intentionality, which is supported by ontological movements towards the confirmation of this freedom. Thus, freedom is the first premise of existence, and this condition of a free man that allows the foundation of a moral. In a not too distant perspective we have Thomas Hobbes who denies free will, is deterministic, mechanistic and materialistic. Materialistic because everything that presents itself to the senses of man, including himself, is only a ponderable and apprehensive matter to the human and mechanistic mind in function of the very conception of the movement of matter that is delimited by exact movements as well as the mathematical product. Therefore, freedom is negative. Thus, this article will seek to present the point of view of these two authors, Simone de Beauvoir and Thomas Hobbes and establish a parallel, a possible bridge between them, to understand the concept of freedom.
\end{abstract}

Keywords: Freedom. Existence. Morality. Need. 


\section{Introduçáo}

Ce observarmos o dicionário podemos encontrar três indicaçóes possíveis para a palavra liberdade, primeiro como autodeterminação ou auto causalidade, segundo a qual a liberdade é ausência de condiçôes e de limites; Segunda como necessidade, que se baseia no mesmo conceito da precedente, a autodeterminação, mas atribuindo- a à totalidade a que o homem pertence (Mundo, Substância, Estado); Terceira a liberdade como possibilidade ou como escolha, segundo a qual a liberdade é limitada e condicionada, isto é, finita. (Abbagnano,2007. p. 606).

Para a primeira indicação - ausência de condição e de limite podemos citar as observações dos Estoicos, pois admitiam que eram livres as ações que têm em si mesma causa ou princípio: "Só o sábio é livre, e todos os malvados são escravos, pois liberdade é autodeterminação, enquanto escravidão é falta da autodeterminação" (DlÓG. L, VII,121. Apud Abbagnano. 2007, p.606). Somente a autodeterminação é capaz de oferecer a liberdade efetiva ao homem, pois sem ela, ele é escravo de si mesmo.

Seguindo essa ideia podemos citar Orígenes para quem a "liberdade consiste não só em ter em si a causa dos próprios movimentos, mas também em ser essa causa. Esta definição, que se aplica a todos os seres vivos, privilegia o homem porque a causa dos movimentos, humanos é aquilo que o próprio homem escolhe como móbil, enquanto juiz e árbitro das circunstâncias externas" (Deprinc, III, 5. Apud Abbagnano,2007, p. 606). O homem como responsável por aquilo que lhe acontece, pois é ele a causa de todos os movimentos internos e externos de si mesmo.

Contudo para Sartre, para quem a liberdade é a escolha que o homem faz de seu próprio ser e do mundo.

Mas exatamente por se tratar de uma escolha, na medida em que é feita, essa escolha geralmente indica outras tantas como possíveis. A possibilidade dessas outras escolhas não é explicitada nem proposta, mas é vivida no sentimento de injusüficabilidade e expressa na absurdidade da minha escolha, consequentemente do meu ser. Assim, minha liberdade devora a minha liberdade. Sendo livre, projeto o meu possível total, mas com isto projeto que sou livre e que posso aniquilar esse meu primeiro projeto e relegá-lo ao passado. (apud ABBAGNANO, 2007, p. 608).

Ou seja, aqui Sartre leva ao extremo o antigo conceito de auto causalidade. O homem como responsável por si mesmo.

Para a segunda acepção de liberdade, já citada autodeterminação, porém voltada ao lugar do homem (Mundo, Substancia, Estado). Esta concepção tem estreito parentesco com a primeira. O conceito de liberdade a que se refere é ainda o de causa sui; contudo, como tal, a liberdade é não atribuída à parte, mas ao todo: não ao indivíduo, mas à ordem cósmica ou divina, à Substância, ao Absoluto, ao Estado. A origem dessa concepção está nos Estoicos, para os quais, como vimos, "a liberdade consiste na autodeterminação e, portanto, só o sábio é livre" (DIÓG. L, VII, 121. Apud Abbagnano.2007. p.609). Mas por que o sábio é livre? Porque só ele vive em conformidade com a natureza, só ele se conforma à ordem do mundo, ao destino (DIÓG. L, VII, 88; STOBEO, Flor, VI, 19; CÍCERO, De fato, 17. Apud Abbagnano.2007 p.609). A liberdade do sábio coincide, portanto, com a necessidade da ordem cósmica. 
Enquanto as duas primeiras concepçóes de liberdade possuem um núcleo conceitual comum, a terceira não recorre a esse núcleo porque entende a liberdade como medida de possibilidade, portanto escolha motivada ou condicionada. Nesse sentido, a liberdade não é autodeterminação absoluta e não é, portanto, um todo ou um nada, mas um problema aberto: determinar a medida, a condição ou a modalidade de escolha que pode garanti-la. Livre, nesse sentido, não é quem é causa sui ou quem se identifica com uma totalidade que é causa sui, mas quem possui, em determinado grau, determinadas possibilidades. (Abbagnano.2007. p. 610)

Liberdade assumiu, assim em oposição à noção de livre-arbítrio, a forma de negação. Essa forma é expressa por Hobbes. Este, identificando à vontade com o apetite, afirma que não se pode não querer aquilo que se quer (não se pode não ter fome quando se tem fome, não ter sede quando se tem sede, etc), mas que é possível fazer ou não fazer aquilo que se quer (comer ou náo comer quando se tem fome, etc). Existe, pois, uma liberdade de fazer, não uma liberdade de querer (De hom., II, $\$ 2$; De corp., 25, $\$ 13$. Apud Abbagnano. 2007. p.611).

Dessa maneira segundo Axel Honneth em sua obra 'O direito da liberdade', afirma que para Hobbes liberdade ou independência:

- Significa em sentido próprio a ausência de oposição (entendendo por oposição os impedimentos externos ao movimento) - a liberdade é a ausência de resistências, que poderiam obstruir os movimentos possíveis aos corpos naturais, por essa razáo, obstáculos internos, que no caso de corpos simples, poderiam ter sua origem na composição de sua matéria, não deveriam ser considerados restriçóes à liberdade, já que pertencem as disposições individuais, portanto poderíamos dizer que são autogerados. (HONNETH, 2016, p. 18).

Pode se dizer assim que a liberdade é a ausência de impedimentos aos nossos movimentos. Essa noção pode ser considerada fisicalista, ou seja, considera que o que nos impede pode ser apenas, imposições ou obstruções em relação a esses movimentos.

Também observando a já citada obra de Axel Honneth o mesmo assinala que na modernidade foram constituídas, três modelos claramente delimitados para os conflitos em torno do significado de liberdade, segundo o grau de sua complexidade, para ele, podemos falar de um modelo de liberdade negativo, de um modelo reflexivo e de um social.

Hobbes e Sartre e consequentemente Simone de Beauvoir podem ser alocados no modelo negativo, já que ambos negam o livre arbítrio e impóe de certa forma um peso, a liberdade do homem, ou seja Hobbes compreende como impedimentos ao movimento. Sartre (2011) como fundamento de todas as essências, posto que homem desvela as essências intramundanas ao transcender o mundo rumo às suas possibilidades próprias. Assim a realidade humana segundo Sartre (2011) é livre porque não é o bastante, porque está perpetuamente desprendida de si mesmo, e porque aquilo que foi está separado por um nada daquilo que é e daquilo que será. Assim a liberdade é precisamente o nada que é tendo em si do no âmago do homem e obriga a realidade humana a fazer-se em vez de ser.

Já por sua vez, Simone de Beauvoir (2005) compreende a liberdade relacionando a com a transcendência, ou seja, a possibilidade de estabelecer uma ruptura no mundo pela açáo espontânea, ela identifica na essência do ser livre a incerteza e o risco, liberdade é contingência.

A partir do exposto acima o presente artigo buscará apresentar dentro do modelo negativo constituído por Axel Honneth as concepçóes de liberdade em Thomas Hobbes e em Simone de 
Beauvoir.

Dessa maneira em um primeiro momento o presente artigo apresentará a concepção de Thomas Hobbes e para tal utiliza -se de sua obra magna "O Levita" e também de alguns artigos de comentadores dentre eles o já citado Axel Honneth, e sua obra o 'Direito da Liberdade' de 2016, a tese de Evandro José Machado intitulada "Liberdade e movimento em Thomas Hobbes" de 2011. A tese de Maria Eliane Rosa de Souza intitulada "Thomas Hobbes do movimento físico à fundação do estado", de 2008.

Em sequência o presente artigo trará as concepçôes de Simone de Beauvoir e para tal utiliza-se de sua obra 'O segundo Sexo', do ensaio 'Por uma moral da ambiguidade' e do ensaio 'Pirro e Cinéas', além de alguns artigos dentre eles o artigo de Simone Cristina Jensen "A liberdade para Simone de Beauvoir” publicado no Jornal de Relaçóes Internacionais de 2017. A dissertaçáo de mestrado de Janaina Almeida Ortins Dias "Ambiguidade e liberdade na filosofia moral de Simone de Beauvoir" de 2016. O artigo de Lucas Joaquim Motta "A relação entre ambiguidade, liberdade e condição humana em Simone de Beauvoir”, publicado na revista Filogenese, vol. 11, Marília - São Paulo, 2018.

Para finalizar um balanço das duas concepçóes e como ambas se aproximam, mesmo distantes no tempo, possuem semelhanças quanto ao cerne da questão liberdade.

\section{Hobbes e a liberdade}

Thomas Hobbes (1588 - 1679) viveu na Inglaterra em um período de intensa agitação política, em 1603, Jaime VI da Escócia foi proclamado o novo rei como Jaime I da Inglaterra logo no início de seu reinado, teve de enfrentar alguns conflitos religiosos. Jaime I foi substituído por Carlos I em 1625, contudo assim como Jaime I, Carlos I também enfrentou muitas disputas na Inglaterra em função de açôes do Parlamento, o dissolvendo em 1629, porém em novembro de 1640, Carlos, sem dinheiro, convocou ao Parlamento chegando em 1641 a um acordo pacífico com os escoceses. Mas isso náo foi o suficiente, e em outubro do mesmo ano, produziu-se uma nova rebelião na Irlanda. Muitos protestantes foram assassinados. Os católicos ingleses apoiaram os irlandeses. A Confederação Católica, com seu próprio Parlamento, este liderada por Owen Roe O’Neill. O Parlamento temeu que Carlos I utilizasse o exército formado para sufocar a rebelião contra seus próprios súditos. A Grande Protesta exigiu a nomeação de ministros com a confiança do Parlamento, a permissão das práticas calvinistas e a supervisão por parte do Parlamento do exército destinado a Irlanda. Carlos I negou a solicitaçáo, em 3 de janeiro de 1642, enviou o Fiscal Geral do Estado à Câmara dos Lordes para pesar um processo por alta traição a vários Comuns. A tentativa precipitou a guerra civil que durou de 1642 a 1649, encerando com a decapitação de Carlos I em 30 de janeiro de 1649.

Após a morte de Carlos I houve uma tentativa de implementar na Inglaterra uma República liderada por Oliver Cromwell, porém a República fracassou e em 1660 Carlos II assumiu o trono e restaurou a Monarquia na Inglaterra.

Durante esse período Thomas Hobbes esteve isolado na França, onde escreveu o "Leviatâ", foi lá também que Hobbes frequentou o Círculo de Mersenne, onde pode ter contato com a obra de Descartes. Em 1646, ainda em Paris, torna-se professor de matemática do Príncipe de Gales, o futuro Carlos II, que também se encontrava exilado em Paris devido à Guerra Civil 
Inglesa. Em 1651, dois anos após a decapitação do rei Carlos I, e o fim da Guerra Civil, Hobbes decide voltar a Inglaterra. Neste ano, chegam às livrarias inglesas a primeira versão do "Leviatâ".

O "Leviatâ" por sua vez é a obra mais expressiva de Thomas Hobbes, um tratado político que a muito gera polêmica, dada às questôes e interpretaçóes geradas por essa obra prima do pensamento político moderno. Neste artigo, porém, como já foi anteriormente citado, iremos tratar do tema da liberdade, que assim como outras questóes em Hobbes também gera muitas discussóes.

Liberdade segundo Thomas Hobbes é a ausência de impedimentos externos ao movimento, ou seja, "a ausência de impedimentos, estes que muitas vezes tiram parte do poder que cada um tem de fazer o que quer, mas não podem obstar a que use o poder que lhe resta, conforme o que o seu julgamento e razão lhe ditam”. (HOBBES. 2008, Cap. XIV, p.112).

Segundo Axel Honneth (2016) a ideia de que a liberdade do indivíduo consiste na busca de seus próprios interesses sem que haja impedimentos 'de fora' repousa numa arraigada intuição do indivíduo moderno. Segundo essa ideia, o próprio sujeito detém um direito a especificidade, a qual ele se apega por seus desejos e intençôes que não estão submetidas a nenhum controle de princípios de graus mais elevados. É por essa razão, em Hobbes, o livre estabelecimento de objetivos, que podem valer como fins legítimos de açóes livre, inspirou, no sentido contrário ao de suas próprias convicçôes, o surgimento de um pensamento da liberdade cuja principal preocupação é a defesa das idiossincrasias.

Para Evandro José Machado em sua tese "Liberdade e movimento em Thomas Hobbes" afirma que o "movimento do corpo, é a condição fundamental para se entender a liberdade humana, ou seja todo corpo existe para o movimento e está em constante movimento" (MACHADO. 2011, p. 12). Segundo o autor isso se justiça porque o movimento do corpo humano é igual a vida e a paralisação do movimento vital é igual a morte. Ou seja, o homem não pode deixar seu movimento vital parar, de maneira que ele é totalmente livre para desenvolver o que é lhe é necessário e conveniente para a preservação de seu movimento vital.

Assim quando Hobbes afirma que a liberdade é ausência de impedimentos ao movimento, isso significa que há uma relação de causalidade. Ou seja, o movimento é constituído pela ausência de impedimentos que por sua vez estão diretamente ligados por uma relação de causalidade, que compreende ser o movimento e as ações decorridas desse movimento provocado nos corpos.

Para entendermos essa noção de movimento observamos a seguinte citação de Evandro J. Machado, 2011:

O movimento é um processo causal, pois é ele quem causa nos corpos o surgimento do movimento. Quando um corpo está em repouso, ele exige, necessariamente, a ação de outro corpo, para que inicie nele o movimento. Assim, é o processo de movimento que opera sobre os corpos e náo os corpos que se movimentam por si. Os corpos não causam movimento, eles apenas são movidos por outros corpos que também estão sendo movidos". (MACHADO, 2011, p. 28).

Dessa forma, para Hobbes, toda mudança é movimento e todo movimento gera movimento vinculado a mudança. Assim, segundo Hobbes:

Quando uma coisa está em repouso, permanecerá sempre em repouso, a não ser que algo a coloque em movimento. Mas esta outra afirmação não é tão facilmente aceita, muito embora a razão seja a mesma, quando alguma coisa está em movimento, permanecerá eternamente em movimento, a não ser que algo a 
pare. (HOBBES, 2008, p.17).

Portanto, para Hobbes (2008) nada se move sozinho tudo o que se move precisa necessariamente ser movido por algo ou alguém externo a si. Uma vez em movimento, um corpo move-se eternamente, e apesar de tudo o possível não o pode extinguir num só instante, a não ser que algo o impeça, que algo de súbito lhe pare.

Para Maria Eliane Rosa de Souza em sua tese intitulada, "Thomas Hobbes, do movimento físico à fundação do Estado" de 2008, Hobbes busca no conceito de conatus uma forma de justificar o movimento nos corpos como:

O conatus justifica a existência de movimentos nos corpos, sem nenhuma determinação prévia e com inclinação dada pelo próprio movimento. Afirmar, então, o conatussignifica afirmar que os corpos possuem movimentos imperceptíveis que, na ausência de obstáculos, têm como direção o próprio movimento. Pelo conceito de conatus, Hobbes considera que os corpos possuem movimentos que explicam o fato deles se moverem ininterruptamente sem nenhuma inclinação ou direção previamente determinada, desde que não haja nenhum obstáculo. (SOUZA, 2008, p. 118).

E isso nos leva a noção de Conatus ou Endeavour que é o termo utilizado por Hobbes como base de sua física. Na forma latina, o endeavour é denominado conatus. No seu sentido próprio, a palavra latina significa esforço, empenho, tentativa, impulso, e, no sentido figurado, representa uma inclinação ou tendência. De um modo geral, o conatus se caracteriza como uma pequena unidade de matéria que se movimenta infinitamente e de onde procede uma variedade de outros movimentos dependentes de todo o sistema de um corpo, que é compreendida como esforço para Hobbes (2008) este esforço, quando vai em direção de algo que o causa, chama-se apetite ou desejo. Quando o esforço vai em direção contraria de alguma coisa, chama-se geralmente aversão. As palavras de apetite e aversão provém do latim e ambas designam movimentos, um de aproximação e outro de afastamento. Desta forma a própria natureza impóe aos homens certas verdades, com as quais depois eles irão topar quando procurarem algo além da natureza. Aquilo que os homens desejam pode se dizer que amam, e que odeiam as coisas pelas quais sentem aversão. Desejo e amor são semelhantes entre si, porém desejo é quando o objeto não está presente e amor quando ele nos aparece. Assim como aversáo e ódio sáo semelhantes, da mesma forma que desejo e amor, aversão é quando o objeto não está presente e ódio quando ele nos aparece.

Alguns desejos e aversóes são inatos ao homem, como por exemplo o desejo pelo alimento ou a aversão ao frio ou calor intenso. Mas em geral os apetites por coisas específicas, provém da experiência, e a comprovação de seus efeitos sobre os corpos. Porque todas as coisas que não conhecemos, não podemos ter outro desejo que não seja o de prová-las. Porém podemos ter aversão às coisas que sabemos que nos causam danos, mas não só pelas coisas que conhecemos, mas também pelas quais desconhecemos os danos que podem nos causar. Quanto às coisas que não nos causam nem desejo, nem aversão podem ser chamadas de desprezíveis, pois este não é outra coisa senáo, uma imobilidade do coração, ao resistir à ação de certos objetos. Isso se deve ao coração já ser movido por objetos mais potentes. Ou a falta de experiência daquilo que nos causa desprezo.

Segundo Hobbes (2008), seja qual for o objeto do apetite ou desejo dos homens, este objeto é aquele a que cada um designa como bom; ao objeto que provem seu ódio ou aversão 
designa-se como mau, e ao objeto de desprezo designa-se como sendo vil, insignificante. Pois as palavras "boas", "más" e "desprezíveis", são sempre usadas em relação a pessoa que as usa. Não há nada simples e absolutamente, ou regra alguma comum ao bem e o mal que possa ser extraída da natureza dos objetos. Ela só pode ser tirada de cada um, das pessoas que as representam, ou em caso de discordância em relação a alguma regra, ela poderá ser tirada de em juiz.

Essa questão é aqui brevemente apresentada em função de que para que haja o movimento é necessário, segundo Hobbes um certo esforço e este por sua vez é apresentado a partir do conceito de Conatus, que justamente é o esforço necessário para a realização do movimento externos dos corpos. Aliás, como afirma Souza (2008), a ideia de movimento é o ponto de partida do conceito de conatus, causa universalmente presente em todos os corpos, que justifica a afirmação da filosofia hobbesiana como uma "filosofia do movimento".

Os desejos e vontades são, em última instância, conatus ou movimentos dos corpos causados por outros movimentos sobre os quais o agente pode não ter total controle. Ele é livre para agir ou fazer escolhas em relação aos desejos e vontades, mas não está livre de senti-los porque é sempre um ser em movimento. $\mathrm{E}$ a razão disso é que o agente representa, no sentido físico, continuamente um ser de desejo e, enquanto viver, estará submetido a uma cadeia de movimentos e sentimentos variados e intermináveis a definir a vida humana como uma marcha infinita. (SOUZA, 2008, p. 132).

Mas o que nos interessa aqui efetivamente é compreender como o esforço que leva ao movimento pode ser a condição de possibilidade para o exercício da liberdade em Thomas Hobbes. E isso, portanto nos leva novamente a noção de liberdade apresentada por Hobbes que segundo Souza pode ser expressa da seguinte maneira, a liberdade como "a ausência de todos os impedimentos à ação que não estão contidos dentro da natureza e da qualidade intrínseca do agente". (HOBBES, LN, p. 108, apud SOUZA, 2008, p. 146). Dessa forma para Hobbes, quando o impedimento é interno, não há perda da liberdade, porém não se tem o poder de fazer o que se quer, todavia quando o impedimento é externo, há a ausência da liberdade. Assim o homem é livre quando não há impedimentos externos de agir conforme sua vontade e natureza. Para Souza, "É exatamente no objeto da vontade e do desejo que se pode identificar a liberdade do agente, quando a ele não é imposta nenhuma barreira externa que o impeça de alcançar o objeto de sua vontade" (SOUZA, 2008, p. 146).

As necessidades do indivíduo são as causas primeiras para desencadear nele o princípio do movimento, quando há necessidades os indivíduos buscam por meio do esforço necessário, endeavour, dar início ao movimento e este por sua vez indica a liberdade de o indivíduo moverse em direção a sanar a necessidade que o impulsionou ao movimento. Para Hobbes a vontade existe de maneira fisiológica como uma necessidade, porém sua causa não se encontra nela mesma, mas sim em outras coisas das quais ela depende externamente. Ou seja, quando alguém tem fome, é inquestionável a necessidade de se alimentar, e se o indivíduo não encontra nada fora de si que o impeça ele poderá sanar sua fome como melhor lhe convém, permanecendo assim livre em sua deliberação. É exatamente no objeto da vontade e do desejo que se identifica a liberdade dos indivíduos. Pode se dizer, entretanto, que as ações voluntárias são acompanhadas da necessidade de uma vontade sempre interna, mas são, ao mesmo tempo livres quanto o objeto dessa vontade não lhe é imposto nenhum impedimento. Em contrapartida, a ausência de liberdade é identificada apenas quando somos impedidos externamente de alcançar o objeto 
de nossa vontade. Assim o indivíduo se vê condicionado internamente permanece no espaço da mais completa liberdade, caso não seja impedido externamente de mover-se em direção ao objeto de sua vontade.

E, portanto, segundo Hobbes (2008), liberdade significa em sentido próprio, a ausência de oposição, (aqui entendida como impedimentos externos ao movimento), porque tudo o que estiver amarrado ou envolvido de modo que não se possa mover senão dentro de um certo espaço, sendo esse espaço determinado pela oposição de algum corpo externo, dizemos que não tem liberdade de ir. Mas quando o que impede o movimento faz parte da constituiçáo da própria coisa não costumamos dizer que lhe falta liberdade, mas que lhe falta o poder de se mover. A liberdade constitui assim a ausência de impedimentos externos ao movimento do homem, a falta de liberdade consiste por sua vez na existência de impedimentos internos ao movimento do homem, livre sou para escolher a qual apetite ou desejo irei satisfazer, já que os mesmos dependem de minha deliberação, e sendo assim "um homem livre é aquele que, naquelas coisas que graças à sua força e engenho é capaz de fazer, não é impedido de fazer o que tem vontade de fazer". (HOBBES, 2008, p. 179). Dessa forma a liberdade não está contida nos objetos, mas sim no homem, e no fato de ele náo deparar com entraves ao fazer aquilo que tem vontade, desejo ou inclinação de fazer.

A partir disso podemos observar que há duas expressão de liberdade em Hobbes, uma que diz respeito a liberdade como ausência de impedimentos externos ao movimento, essa forma liga-se ao conceito de conatus ou endeavour, que é o esforço presente no movimento, como uma partícula, que leva ao movimento, pois na fórmula básica um objeto em movimento permanece em movimento a não ser que algo externo a si o faça parar, e por sua vez em sua forma contrária afirma que um objeto em repouso permanece em repouso até que algo o movimente, e as duas formas são válidas se considerarmos a física hobbesiana.

A outra forma expressa para a liberdade em Hobbes consiste na ausência de impedimentos externos ao movimento, contudo aqui ligado ao homem, externo a ale não há nada que o impeça de agir conforme sua vontade e deliberação, mesmo quando algo impede externamente o homem de mover se, como uma doença que o prende ao leito, ainda há liberdade em suas deliberaçóes, pois o que lhe falta é o poder de se mover e não a liberdade para mover-se. O impedimento é somente interno, cabe apenas ao homem atender ou não suas vontades e desejos. Mesmo que não cabe ao homem sentir ou não determinados apetites ou aversão, a escolha reside em atender ou não a tais apetites e aversôes, não posso não sentir fome quando estou com fome, não posso não sentir sede quando estou com sede, mas posso, se não há impedimentos externos, encontrar a melhor maneira de sanar minha fome e minha sede.

Contudo ainda é necessário destacarmos que no estado de natureza constituído por Hobbes, a liberdade dos indivíduos é mais ampla, pois o que lhe impede é sua própria força ou condição de fazer algo. Os impedimentos ao movimento do homem em estado e natureza são menos do que os impedimentos do homem em estado civil, pois em estado civil há um impedimento externo muito forte e limitante a liberdade, que Hobbes chama de Lei. A lei é a principal forma, e única em estado civil que impede ao homem de agir livremente, como já foi destacado anteriormente não posso não sentir fome quando estou com fome, mas posso escolher qual a melhor maneira de sanar minha fome, pois possuo o direito de o fazer, em estado civil está melhor maneira será aquela que a lei me permitir, se em estado civil a melhor maneira, ou a 
única a minha disposição será me apropriar de algo que não me pertence serei impedido pela lei e se o fizer serei punido pela lei.

Hobbes (2008) destaca que a lei é um preceito ou regra geral, estabelecido pela razão, mediante o qual se pró́be a um homem fazer tudo o que possa destruir a sua vida ou priva-lo dos meios necessários para a preservar, ou omitir aquilo que pense melhor contribuir para a preservar. Porém como destaca Hobbes (2008) o direito consiste na liberdade de fazer ou omitir, ao passo que a lei determina ou obriga uma dessas duas coisas. De forma que a lei e o direito se distinguem tanto como a obrigação e a liberdade, as quais são incompatíveis quando se referem a mesma questão.

Assim o homem possui o direito de escolher - liberdade de fazer e atender as suas paixões como melhor the convém, porém em estado civil, o impedimento a esse movimento, que Hobbes afirma ser natural aos corpos, é impedido pela lei, deixando o homem livre e determinado ao mesmo tempo.

Desta forma podemos partir para a segunda parte do presente artigo onde buscaremos compreender como a filósofa Simone de Beauvoir apresenta suas concepções de liberdade.

\section{Beauvoir e a liberdade}

Simone de Beauvoir nasceu em 1908 e viveu até 1986 em Paris na França, também em um momento histórico particular, quando jovem 1914 a 1918 eclodiu em toda a Europa a $1^{\circ}$ Guerra Mundial, motivada por disputas políticas contrárias às políticas imperialistas que dominavam todas as naçóes europeias, levaram mais de 9 milhôes de combatentes ao campo de batalha, tornando-se assim uma das mais sangrentas guerras do século XX, isso até chegarmos a 1939 quando novamente na Europa eclode a $2^{\circ}$ Guerra Mundial, logo em 1917 na Rússia estourou umas das mais importantes revoluçôes socialistas do século XX, isso impactou não somente a Europa, mas a todo o mundo, e com isso mais agitação e transformaçóes sociais impulsionaram mudanças profundas na sociedade europeia e na vida particular de Simone de Beauvoir, seus pais e familiares foram impactados fortemente por tais mudanças, de maneira a mudar o rumo da vida de Beauvoir, não mais predestinada ao casamento, mas sim a magistratura, que após uma educaçáo estritamente católica, opta por fazer seus estudos em filosofia na Sorbonne, e de aulas até 1943, que poderia ser algo melhor para ela e sua irmá. Em conjunto a isso, em 1918, mais uma vez o mundo é impactado por uma doença grave que leva mais de 500 milhóes de pessoas a morte em poucos dias, tem se a gripe espanhola que junto com guerra matou milhóes de pessoas em todo mundo.

A Europa estava em trapos, os impérios haviam caídos, o que restava eram fracas repúblicas que buscavam se reerguer em meio ao caos. Mais nada está tão ruim que não possa ficar pior e em pouco mais de 10 anos o mundo, em especial os Estados Unidos, mergulharam em uma profunda crise econômica gerada pelo capitalismo financeiro. Com isso o mundo sofre um novo abalo de suas estruturas, as fracas repúblicas veem acender os regimes totalitaristas e fascistas que levam ao mundo em 1939 a $2^{\circ}$ Guerra Mundial, mais mortal e violenta que a $1^{\circ}$, de forma que seus impactos envolvem todas as nações mundiais. Estados Unidos, URSS e Alemanha enfrentase no campo de batalha e levam mais de 70 milhóes a morte, dentre eles mais de 6 milhóes de Judeus que foram perseguidos e mortos pelo regime nazista alemão. 
Sendo assim nada, nem ninguém em todo mundo pode ser indiferente a todos esses acontecimentos, e claro que eles tiveram impactos diretos não somente sobre a sociedade e a vida de Beauvoir, mas também sobre sua obra em desenvolvimento. E em 1949 chegava às livrarias francesas sua mais impactante e importante obra filosófica, "O segundo sexo", importante porque a coloca entre as mais importantes filósofas do século XX, impactante porque esse tratado traz pela primeira vez uma análise ampla e clara da condiçáo da mulher na sociedade europeia.

Os tabus, os medos e preconceitos que as mulheres enfrentam ao longo de sua existência, estavam todos ali reunidos em uma análise profunda e detalhada de cada fase, e sob diversos aspectos desse ser que "não nasce mulher, torna-se mulher". (BEAUVOIR, 2009).

Segundo Janaina Almeida Ortins Dias, em sua dissertação "Ambiguidade e liberdade na filosofia moral de Simone de Beauvoir” de 2016, Beauvoir, como uma filósofa representante do século XX, apresenta várias preocupaçóes do seu tempo, dentre elas o fracasso da experiência socialista na Rússia, que teve como principal consequência a restrição das liberdades individuais no país e o avanço do individualismo burguês, que só fez aumentar o abismo entre as diferenças sociais já gritantes. Talvez essa seja a razão para que a sua filosofia esteja centrada em uma perspectiva política e histórica. Ao repensar este indivíduo no âmbito de uma ontologia que de forma alguma está dissociado com a realidade, adentramos no universo de 1947, no qual os acontecimentos históricos, foram fundamentais para o amadurecimento de suas análises filosóficas.

Beauvoir (2009) observa que o código francês não mais incluía a obediência entre os deveres da esposa, e toda cidadã tornara-se eleitora; essas liberdades cívicas permanecem abstratas quando não estão acompanhadas de autonomia econômica. Segundo Beauvoir (2009) a mulher sustentada não se liberta do homem por poder votar, se os costumes ainda a impóe obstáculos, ela continua em sua condição de vassala. Assim foi pelo trabalho que a mulher cobriu grande parte da distância que a separava do homem; só o trabalho pode assegurar uma liberdade concreta. Porém ainda hoje o trabalho não é a liberdade. Ainda aprisiona e oprime a mulher para sua condição de vassala. $\mathrm{O}$ trabalho remunerado náo exclui o trabalho doméstico ou invisível, pois não é considerado 'trabalho', e assim a jornada que recai sobre a mulher é não mais dupla, trabalho formal, trabalho doméstico, mas sim ininterrupta, contínua, ela apenas 'descansa' quando está dormindo.

Segundo Kete Kirtpatrick em sua obra "Simone de Beauvoir: uma vida” de 2020, Beauvoir insistia na ideia de distinguir "vida" e "trabalho" como se "trabalhar" não fosse viver e "vida" não exigisse trabalho.

A partir disso recai sobre nós a seguinte questão, o que de fato é a liberdade para Simone de Beauvoir. O trabalho como já apontado, contribui na busca pela liberdade feminina, mas em si não é a liberdade necessária e própria. Beauvoir (2009) afirma que em sua maioria os trabalhadores hoje ainda são explorados, a estrutura social não foi suficientemente modificada pela evoluçáo da condiçáo feminina; este mundo, que sempre pertenceu aos homens, conserva ainda a forma que eles lhe imprimiram. Atualmente, em sua maioria as mulheres que trabalham não se evadem do mundo feminino tradicional; não recebem da sociedade, nem do marido, a ajuda que lhes seria necessária para se tornarem concretamente iguais aos homens. E, portanto, livres.

A ideia de liberdade expressa por Beauvoir se aproxima em muito da ideia de liberdade 
expressa por Sartre, segundo Simone C. Jensen, em seu artigo "A liberdade para Simone de Beauvoir" 2017. A liberdade "não é um ser, ela é o ser do homem, isto é, é o seu nada de ser. A liberdade é constitutiva da consciência”. É na própria liberdade que o homem encontra as bases de sua conduta. Assim para o homem encontrar as bases de sua conduta de modo que sua atitude seja autêntica, é necessário tornar-se livre dentro do mundo, porém o mundo já é pré estabelecido, já está cheio de valores e comportamentos que definem e limitam os indivíduos em busca de sua liberdade. O exercício pleno da liberdade sempre foi impossibilitado ou dificultado pela moral unitária em meio a multiplicidade. Segundo Kirkpatrick (2020) esse é um dos principais insigths filosóficos de Beauvoir porque todo ser humano é situado em um contexto particular, em um corpo particular, em um lugar, tempo e nexo de relacionamentos específicos. Essa situação molda a capacidade de cada indivíduo de imaginar seu lugar no mundo, e muda ao longo da vida. Além disso, no caso das mulheres, essa situação foi moldada por séculos de sexismo.

Deste ponto de vista, a vida só pode ser pensada a partir da ambiguidade, pois para que o indivíduo possa exercer sua liberdade existencial de modo comprometido é necessário a ele, emancipar se dos rótulos e da moralidade vigente. Não é possível liberdade em uma sociedade moralmente fechada. A moral da ambiguidade busca o comprometimento do indivíduo e só dele mesmo com sua escolha. E a opção de escolha do indivíduo como ser responsável por tudo o que faz do seu projeto fundamental.

Contudo aqui podemos nos questionar o que é afinal ambiguidade para Beauvoir? Segundo Janaina Dias, em sua dissertação "Ambiguidade e liberdade na filosofia moral de Simone de Beauvoir" de 2016, a ambiguidade pode ser entendida como

O movimento de assumir a condição humana sem tentar evitá-la a partir do fracasso e do êxito. Escolher por essa postura constitui uma atitude autenticamente moral e assim conquistar o grande objetivo humano que é a liberdade. Para tanto, a liberdade não pode ser fruto apenas da glória do homem, mas ela está inserida neste grande pulsar da existência que, sem o fracasso compreendido na singularidade, não poderia ter sentido em si mesma. A liberdade é redesenhar no fracasso novas possibilidades para conquistar a existência que constantemente se falta no próprio ser. (DIAS, 2016, p. 6).

Portanto, segundo Dias (2016), a ambiguidade está inserida nesse movimento existencial que já nasce naturalmente com o homem, mas que ele pode transformar em consciência. Compreender o que é ambiguidade é de fundamental importância para a compreensão do conceito de liberdade em Simone de Beauvoir, pois é em seu ensaio justamente intitulado de "Por uma Moral da ambiguidade" de 1947 que Beauvoir busca analisar esse conceito, de liberdade e sua relação com a ambiguidade e a exigência humana.

A liberdade é a fonte que surgem todas as significações e todos os valores, ela é a condição original de toda justificação da existência; o homem que busca justificar sua vida deve querer antes de tudo e absolutamente a própria liberdade: ao mesmo tempo em que ela exige a realizaçáo de fins concretos, de projetos singulares, ela se exige universalmente. Ela não é um valor inteiramente constituído que se apropria de fora a minha adesão abstrata, mas aparece como causa de si: Quererse moral e querer-se livre é única e mesma decisão. (BEAUVOIR, 2005. p. 26).

Para Beauvoir (2005) ou bem a possuímos (a liberdade) ou bem não a possuímos; mas na verdade ela se confunde com o próprio movimento dessa realidade ambígua que chamamos 
existência e que só é fazendo-se ser; de tal maneira que, precisamente, é apenas na medida em que deve ser conquistada que ela se dá. Todo homem é originalmente livre no sentido de que se lança espontaneamente no mundo.

Para Motta (2018) Simone de Beauvoir se destaca por refletir a liberdade, devido tal liberdade ser a própria substância do sujeito fático, isto é, do sujeito que se realiza como ser humano e, com razão, que se descobre no mundo. É necessário segundo Motta admitir que a vontade de ser livre se desenvolve ao longo do tempo, pois é no desenrolar do tempo que visamos o fim e confirmamos a própria liberdade. Assim, nos deparamos com a ideia de ação. A ação seria aquilo que participa e, ao mesmo tempo, constrói a liberdade. Nesse sentido, segundo Beauvoir, supóe-se que a liberdade se realiza como unidade através do fracionamento do tempo, ou seja, como uma necessidade.

Para Motta (2018), todo sujeito é livre a partir do instante em que se lança no mundo. Esse lançamento é uma espontaneidade original para que o sujeito alcance a legitimidade da sua presença no mundo. No fundo de um plano moral, a liberdade está presente como causa de si e causa das possibilidades do ato moral. Com base nisso, a liberdade é causadora de todos os fundamentos, isto é, de todo o conjunto de normas que tornam possível a existência. "É então contraditório repelir com horror o momento da escolha, que é precisamente o momento da passagem do espírito para a natureza, o momento da realização concreta do homem e da moralidade”. (BEAUVOIR, 2005, p. 25).

Dessa escolha ou vontade, segundo Beauvoir (2005) se desenvolve ao longo do tempo; é ao longo do tempo que o fim é visado e que a liberdade se confirma a si própria, e isso supóe que ela se realiza como unidade através do fracionamento do tempo.

O tempo, a necessidade e a condição ambígua são as bases para a liberdade e a moralidade em Simone de Beauvoir. Assim segundo Motta (2018) a liberdade para Beauvoir é a fonte para que o sujeito se realize no mundo e, com razáo, exerça seus projetos de vida. Nessa perspectiva, ao refletirmos a liberdade, percebemos que ela é ambígua, pois temos um querer livre e um querer moral, sendo ambos a única e a mesma decisão.

A ambiguidade é uma condição para a existência fática e ela se direciona ao sujeito que se realiza no mundo. O sujeito não é um ser totalizado, logo ele busca o ser. Desse modo, a busca do ser ocorre no mundo que próprio funda a todo instante. E, com razão, é neste mesmo mundo que se desvela a existência do indivíduo. (MOTTA, 2018, p. 7).

Para Beauvoir, é indiferente o homem indagar a si próprio sobre sua utilidade no mundo e se a vida vale a pena ser vivida, porque para ela estas questóes são destituídas de sentido, isto é, afastadas de uma ideia original. Com razão, o ser humano, através da sua própria liberdade, gera ao seu redor uma carga de responsabilidades dentro de um mundo que ele mesmo irá desvelar. Por fim, "cabe ao homem fazer com que seja importante ser homem, e apenas ele pode experimentar seu êxito ou seu fracasso” (BEAUVOIR, 2005, p. 20).

O homem se posiciona em direção a sua própria liberdade para, assim alcançá-la. Porém “[...] querer ser livre é efetuar a passagem da natureza à moralidade fundando na irrupção original de nossa existência uma liberdade autêntica” (BEAUVOIR, 2005 p. 26). Em outras palavras, é uma passagem original e inevitável para tornar possível a existência. Por isso que é uma fundação do ato livre do homem que o permite realizar e afirmar ao máximo seu projeto. A realizaçáo 
da liberdade seria um escape para outrem quando, colocada a presença do objeto, o sujeito se posicionaria diante dele como pura presença e liberdade de ser e de escolher.

\section{Conclusáo}

Tratar do tema da liberdade na filosofia e no pensamento humano sempre foi um desafio, desde os antigos, Platão, Estoicos, Cícero, os medievais, Orígenes, Santo Agostinho, os modernos, Thomas Hobbes, e os contemporâneos como Jean Paul Sartre e Simone de Beauvoir entre outros. Enfrentaram esse tema de maneira aberta, ou seja, observando suas mais variadas dimensôes, possibilidades e consequências, aqui apresentamos as observaçóes feitas por Thomas Hobbes e Simone de Beauvoir, cada um a seu tempo, depararam-se com esse conceito analisando em suas dimensões. Para Hobbes uma dimensão física, mecânica e política. Para Simone de Beauvoir uma dimensão fenomenologia, ontológica e política. E entre eles uma ponte possível, uma ligação em sentido tão amplo quanto o próprio conceito de liberdade aqui explorado.

Sendo assim podemos concluir que para Hobbes assim como para Simone de Beauvoir a liberdade se apresenta a partir do modelo de Axel Honneth, de forma negativa, o modelo negativo consiste na ideia de autodeterminação ou que a liberdade não é livre arbítrio, tampouco uma dádiva divina dada aos homens, esse modelo ganhou forma com as guerras civis e religiosas do século XVI e XVII, e foi justamente Hobbes quem primeiro conduziu as partes em conflito para a via de uma ideia apenas negativa de autodeterminação individual "Liberdade ou independência" enuncia em uma passagem do Leviatã "significa em sentido próprio, a ausência de oposição, ou ausência de impedimentos externos, que poderiam obstruir os movimentos possíveis aos corpos naturais”.(HONNETH, 2016).

Em Hobbes podemos observar duas acepções ou duas formas distintas e complementares de compreender a referência acima, a primeira refere-se a ausência de impedimentos externos ao movimento, lembrando que movimento em Hobbes consiste na ideia expressa por Evandro J. Machado, 2011 da seguinte forma:

O movimento é um processo causal, pois é ele quem causa nos corpos o surgimento do movimento. Quando um corpo está em repouso, ele exige, necessariamente, a ação de outro corpo, para que inicie nele o movimento. Assim, é o processo de movimento que opera sobre os corpos e não os corpos que se movimentam por si. Os corpos não causam movimento, eles apenas são movidos por outros corpos que também estão sendo movidos". (MACHADO, 2011, p. 28).

Ou seja, o movimento é um processo causal decorrente do esforço, conatus, nos corpos, pois um corpo em movimento permanece em movimento até que algo externo a ele o pare, assim como um corpo em repouso permanece em repouso até que algo o coloque em movimento. Essas acepçóes decorrem do modelo fisicalista e mecanicista construídos por Hobbes em sua obra.

A segunda acepção de liberdade construída por Hobbes também decorre da ideia de a liberdade ser a ausência de impedimentos externos ao movimento, porém aqui atribuída ao homem em sociedade e não a corpos físicos. Sendo assim tudo o que impede o homem de agir conforme sua vontade e deliberação é a lei, pois ela o impedimento externo existente no estado civil. E portanto é o limite a liberdade, contudo Hobbes observa que a liberdade difere de poder, pois nem sempre tenho poder de fazer algo, mas sempre terei a liberdade interna de o fazer, minhas paixôes e vontades são o motor para minhas açôes, contudo cabe ao indivíduo escolher qual paixão ou vontade e de qual forma irão satisfazer tais paixôes e vontades, assim o homem é 
livre e determinado ao mesmo tempo, determinado por suas paixóes, livre para escolher, dentro da lei, que é o limite externo no estado civil, a melhor maneira de as satisfazer.

Já para Simone de Beauvoir a liberdade consiste na ambiguidade moral dos indivíduos, a ambiguidade é aqui entendida como uma condição de possibilidade para a liberdade, pois ambiguidade segundo Janaina Almeida Ortins Dias, é "o movimento de assumir a condiçáo humana sem tentar evitá-la a partir do fracasso e do êxito. Escolher por essa postura constitui uma atitude autenticamente moral e assim conquistar o grande objetivo humano que é a liberdade". (DIAS, 2016, p. 6). Portanto ambiguidade é o pressuposto constituído por Beauvoir para a liberdade.

Para Dias, (2016) liberdade em Beauvoir está intrinsecamente ligada à liberdade do outro, na medida em que somos seres no mundo. Nascemos em uma sociedade impregnada de valores, mas existe a possibilidade da liberdade do porvir que é necessária e acontece enquanto movido pelo engajamento e pela responsabilidade para consigo e para com o outro.

A liberdade também em Beauvoir além de ambígua constitui-se no tempo, e na necessidade de se fazer livre, pois para ser livre é necessário querer livre o outro.

\section{Referências}

ABBAGNANO. Nicola. Dicionário de filosofia. 5ed. São Paulo. Martins Fontes, 2007.

BUENO. Marcelo. A gênese do conceito de liberdade no pensamento de Thomas Hobbes. São Paulo, 2009.

BEAUVOIR. Simone. O segundo sexo. Tradução Sérgio Milliet. $2^{\circ}$ ed. Rio de Janeiro. Nova Fronteira, 2009.

BEAUVOIR. Simone. Por uma moral da ambiguidade. Tradução Marcelo Jacques de Moraes. Rio de Janeiro. Nova Fronteira, 2005.

DIAS. Janaina Almeida Ortins. Ambiguidade e liberdade na filosofia moral de Simone de Beauvoir. Fortaleza, Ceará, 2016.

HOBBES. Thomas. O Leviatá. Org. Richard Tuck. $2^{\circ}$ ed. São Paulo. Martins Fontes, 2008. (Clássicos Cambridge de Filosofia Política).

HONNETH. Axel. O direito da liberdade. Tradução Saulo Krieger. São Paulo. Martins Fontes, 2016. E-BOOK disponível em

https://books.google.com.br/books/about/O_direito_da_liberdade. html?id=utBJDwAAQBAJ\&printsec=frontcover\&source=kp_read_button\&redir_ esc $=\mathrm{y} \# \mathrm{v}=$ onepage $\& \mathrm{q} \& \mathrm{f}=\mathrm{false}$

JENSEN. Simone Cristina. A liberdade para Simone de Beauvoir. Jornal de relaçôes internacionais. Curitiba, 2017. Disponível em http://jornalri.com.br/artigos/liberdade-parasimone-de-beauvoir/attachment/nov-2017-simone-cristina-jensen-a-liberdade-para-simone-debeauvoir

JOHANSON, Izilda. Moral da Ambiguidade e Libertaçáo: Filosofia e Feminismo em 
Simone de Beauvoir. Revista Ethic@ Florianópolis, Santa Catarina, Brasil, v. 17, n. 2, p. 239 257. Dez. 2018 http://dx.doi.org/10.5007/1677-2954.2018v17n2p239

KIRKPATRICK, Kate. Simone de Beauvoir: uma vida. Tradução Sandra Martha Dolinsky. Editora Planeta do Brasil. São Paulo, 2020.

MACHADO. Evandro José. Liberdade e movimento em Thomas Hobbes. Toledo, Paraná. 2009.

MOTTA, Lucas Joaquim. A relaçáo entre ambiguidade, liberdade e condição humana em Simone de Beauvoir. Revista Filogenese Vol. 11, 2018. www.marilia.unesp.br/filogenese

SOUZA. Maria Eliane Rosa de. Thomas Hobbes do movimento físico a formaçáo do estado. Porto Alegre, 2008. 